\title{
The Determinants of Economic Growth in Central African Republic
}

\author{
Denamguere Thierry Fleury Medard ${ }^{1}$, Andakpara Ndikita Ilamo Sylviane Luce ${ }^{2}$ \\ ${ }^{1}$ Department of Science Economics and Management, Faculty of Management and Engineering, Chongqing University of Posts and \\ Telecommunications, Chongqing, China \\ ${ }^{2}$ Department of Human Resource, Faculty of Science Economics and Business, Douala, Cameroon ( ESSEC) \\ Email address: \\ fdenamguere@yahoo.fr (D. T. F. Medard), Sylviane_andakpara@yahoo.fr (A. N. I. S. Luce)
}

\section{To cite this article:}

Denamguere Thierry Fleury Medard, Andakpara Ndikita Ilamo Sylviane Luce. The Determinants of Economic Growth in Central African Republic. International Journal of Economic Behavior and Organization. Vol. 7, No. 3, 2019, pp. 43-49. doi: 10.11648/j.ijebo.20190703.11

Received: June 26, 2019; Accepted: September 5, 2019; Published: October 25, 2019

\begin{abstract}
The evidence has allowed us to begin first with an introduction and then a literary review on the different aspects of economic growth while demarcating the endogenous and exogenous growth theory affecting the objectives of work while giving the case of C.A.R. The author has not forgotten the empirical literature while developing the different determinants of economic growth (physical, human, technical, etc.). He then returned to the heart of the matter ie showing the point of view on the CAR that is considered a very special case and go into detail with macroeconomic rules. These rules were based on the method of Cobb Doublas which allowed an analysis leading to graphical representations of the different results. The author was also able to summarize each point, followed by strong recommendations to the Central African government to take into consideration. As a result of these various recommendations, the author was able to make a conclusion full of all the specific aspects of this work.
\end{abstract}

Keywords: Determinants, Economic Growth, Central African Republic

\section{Introduction}

Nowadays many African countries are struggling to meet the challenge of economic growth, but some of its countries feel concerned for the well-being of their people. Broadly thought, there has been a problem of political instability that undermines the momentum for sustainable economic growth of some of its countries (the Central African Republic, South Sudan, etc.). Other African countries have managed to improve their level of growth, the reason being that there is good political will that has demonstrated good management of public goods (Ethiopia 7.5\% GDP, Ivory Coast 6.9\% GDP, Senegal / Tanzania 6.8\% GDP, Ghana 5.8\% GDP) in 2017 Mankiw, G., D, Romer and D. Weil, 1992 [1]. As a result, by reasoning in terms of productivity growth, it demonstrates the capacity of a workforce for more productions. This growth in productivity is a foundation for improving real incomes and well-being, Benhabib, J. and A. Rustichinia 1996, Englander and Gurney 1994 [2-3]. Because this growth of productivity considering as one of the more important indicators making it possible to know more the measures of the standard of living of each country.

Thus, in economics, productivity means measuring the degree of contribution of one or more factors of production (material factors consumed or intangible factors implemented) to the variation of the final result of a transformation process. As for economic growth, it is defined as the positive change in the production of goods and services in an economy over a given period, usually a long time. According to François Perroux, economic growth is the sustained increase during one or more periods of a dimension indicator, for a nation, the total net product in real terms in 1961, Coe, Helpman and al. 1997 [4]. So the notion of economic growth is multidimensional and complex, that is to say considering on the plane: geographical, institutional, economic, political etc. The most widely used macroeconomic variable is real gross domestic product (GDP) per capita, which is an indicator of quantitative growth measurement.

Therefore, this article seems to us very essential to seek to determine the economic growth which will be able to consider among others of the short and long term solutions, in order to alleviate the problem of reduction of the poverty in Central 
African Republic. The Central African Republic is a country that has all the possible assets to develop based on a policy of generalized reforms and the fight against the corruption problem that gangrenes the Central African civil service. So this article allowed us to show the stakes that weigh on economic growth in the Central African Republic, in order to give recommendations that will not only help this country to find the way to a real and sustainable development but also to some African countries that are in the same situation to seize this opportunity as some of them who have managed to improve their economic growth sustainably.

\section{The Theorical Literature on the Determinants of Economics Growth}

This literature allows the author of this article to have more insight into the thinking of contemporary economists through their perspective on economic growth that remains a hot topic. Thus, the theory of economic growth is a relatively young field of research. By saying this in the logic or factors of aunt growth to model the mechanisms by which the responsible factors operate (human capital, physical capital etc.), Adam Smith [1776] [5].

\subsection{Theories of Classics on Economic Growth}

These theories according to the classics are rather pessimistic, such as: David Ricardo [1819] [6], Thomas Malthus [1798] [7] or John Stuart Mill, as for them estimating that the economy will reach a stationary state: the growth will slow down, finally reach zero in the long run. Example of the United States. In the same vein according to Ricardo, growth depends on the distribution of income, that is, the more capitalists receive a large share of the profit, the more they will invest. Because investment makes it possible to embark on the program of new jobs. According to neoclassical, three factors are inherent in economic growth:

1. Technological change or innovation

2. The accumulation of capital

3. The increase in the workforce

Thus, neoclassical growth derives its sources (foundations) from the Solow-Swan model by highlighting three main determinants of the constitution of this growth which are: technology, capital and the volume of labor 1956.

\subsection{Solow's Model}

Economic growth is measured on the basis of gross domestic product (GDP) or gross national product (GNP). By the design of Harrod-Domar, Robert Solow proposes in 1956 [8] a model of growth which is the base of the contemporary models. Then that of Harrod-Domar was pessimistic that is to say difficult to reach if one "lets do". Solow's is optimistic because he sees growth as sustainable and stable. The starting point of any theory of growth is the production function, that is, the product relationship (outputs) and the input factors. The production function of two production factors is of the following form:

$$
\mathrm{Y}=\mathrm{F}(\mathrm{K}, \mathrm{L})
$$

Function F tells us what is the output for a capital level $\mathrm{K}$ and a given level of labor L. Then the simplified form of this function is of Cobb Douglas type, that is to say:

$$
\mathrm{F}(\mathrm{K}, \mathrm{L})=\mathrm{K}^{\alpha} \mathrm{L}^{1-\alpha}
$$

The Cobb-Douglas function is a function widely used in economics as a production function model. In this context it was proposed and econometrically tested by the American economist Paul Douglas and the American mathematician Charles Cobb in 1928.

\subsubsection{The Theory Endogenos Growth}

In definition, endogenous growth is a theoretical model of self-sustaining growth. The work of Römer was allowed at the arrival of theories on research and development, the progressive diffusion of technological innovations [1986, 1987, 1990] [9]. Because it is these works that are at the origin of the theories of endogenous growth. According to endogenous growth theorists like Grossman and Helpman [1990], Feenestra [1990] [10], overall productivity is not a residue but must be explained by the behavior of economic agents who accumulate different kinds of capital which, moreover, profit to all, promote the emergence of increasing returns. Then the model of growth of self-sustaining growth accumulates four main factors: physical capital, technological, human capital and public capital, which we will thus schematize.

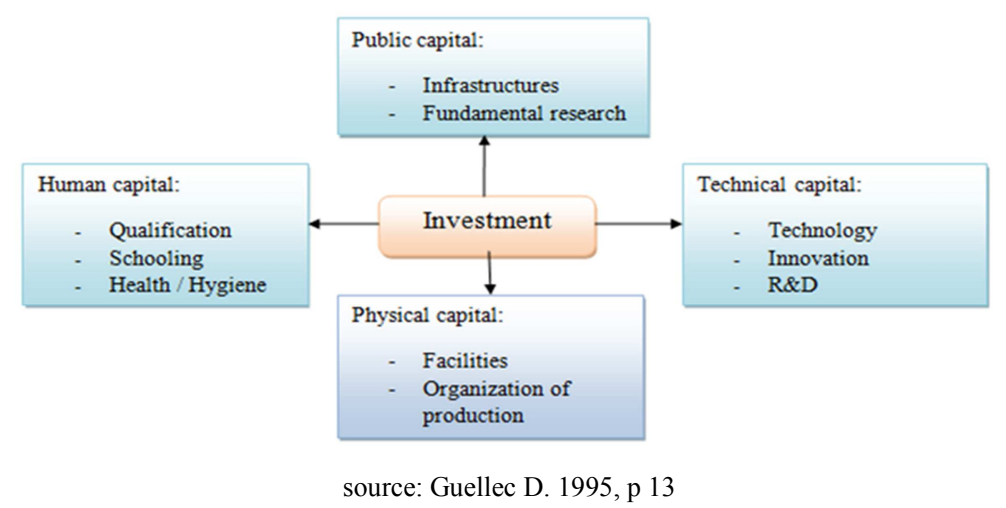

Figure 1. Theories of endogenous growth and the principles of convergence. 


\subsubsection{The Empirical Literature on the Determinants of Economic Growth}

This empirical literature has allowed us to highlight the factors that can enhance economic growth. These refer to the words of different contemporary economists.

\subsubsection{The Phisical Capital}

Physical capital goes in the direction of investing wisely in new equipment. Taking the case of a firm, gives itself the means to increase its own production but also those of other firms competitors or not. There will be the implication of the new technology in order to facilitate the task to the employees. So it will be necessary to put a starting point to new learning by practice, Römer [1986] [11]. In this idea, we want to highlight the combination of the physical and human factor proving more indispensability in the activity of firms.

\subsubsection{Human Capital}

Human capital is a major element that promotes a country's economic growth Barro, R J. 2001 [12]. So human capital is defined as a set of durable dispositions whose acquisition and possession make people more productive in their various activities. According to Mincer, Becker and Schultz thus saying, the fundamental assumption constituting the central element of the human capital theory is that education is an investment that increases productivity. Ballassa, B [1978] [13] In another way, human capital refers to the stock of economically valuable knowledge that is incorporated into individuals. Moreover, it is the sum of all the knowledge acquired in school, in working life and also through work experience according to Bassani and Scarpetta [2001] [14].

\subsubsection{Technical Capital}

Technical capital or physical capital is the totality of the productive assets owned by companies and used to produce goods or services Arellano. M. and S. Bond 1991 [15]. Physical capital consists of real estate and production equipment. It increases with investment in capital goods and, without investment, decreases over time (according to a rate called capital depreciation rate). The diagram below will show us how technical capital works.

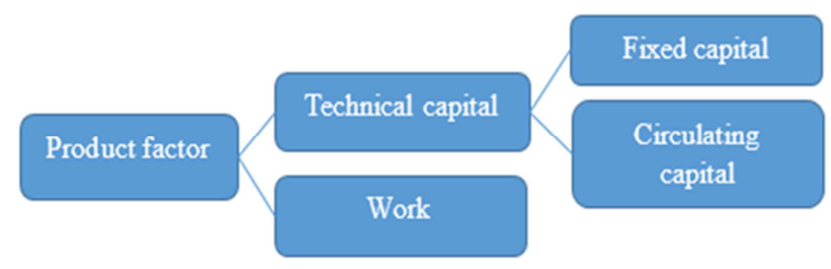

Figure 2. The factors of production.

\section{Export}

Export is defined as the act of selling abroad a portion of the production of goods or services of an economic group, country or region. It is a mirror image of the import term, since a sale from country $\mathrm{X}$ to country $\mathrm{Y}$ is the same as a purchase from country $\mathrm{Y}$ to country $\mathrm{X}$. Exporting also contributes very effectively to the growth GDP of a given country. This is to say that exporting has an important role to play in the economic growth of a country or region Tornell, A. and A. Velasco 1992 Alesina, A. D. Rodrik 1994 [16-17]. Such growth is a result of favorable developments in the factors that enhance the productive capacity and competitiveness of the economy. So then we will graph the graduation of the export of goods and services around the world from 1960 until 2016 below.

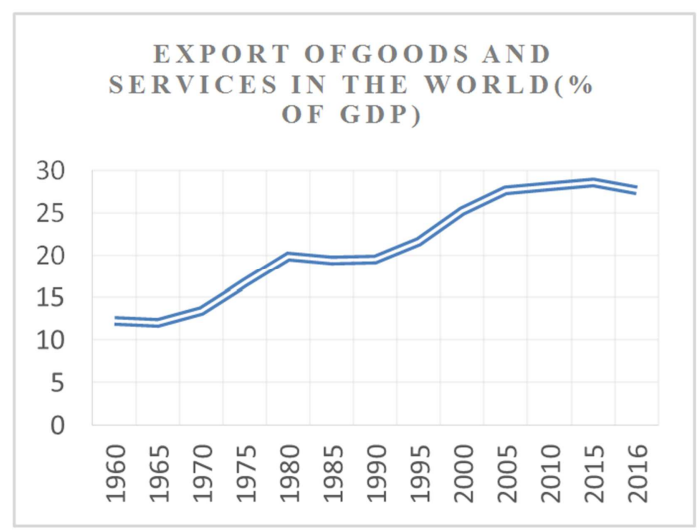

Figure 3. Export of goods and services (\% of GDP).

Source: World Bank National Accounts data and $\backslash$ OECD National Accounts data files.

The term "imports" means in economy all purchases of goods outside a country, whether they are goods intended for consumption (consumer goods) or goods intended to be used for investment (capital goods). In the economic context, a whole country has the interest to import, but it is necessary that the import is in a proportional way to the export, i.e so that it does not have a balance imbalance commercial. The most important thing is to know how to put in place strategies that can regulate so that there is no macroeconomic slippage. Thus, we will present the evolution of the import of goods and services around the world from 1960 until 2016 below.

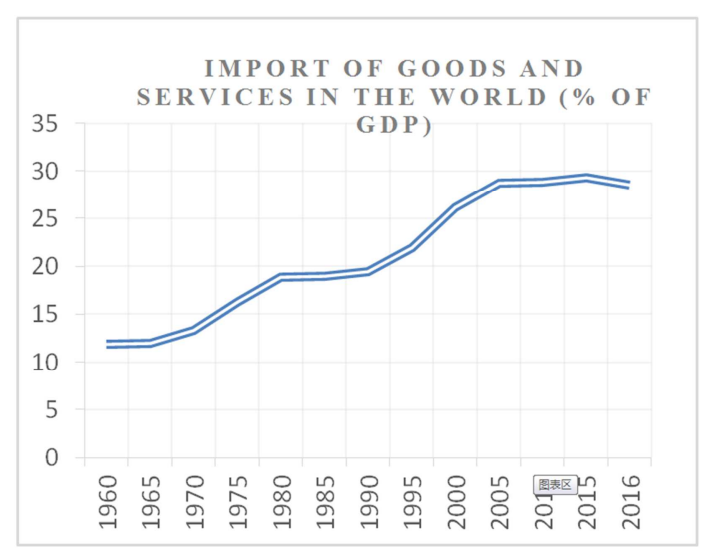

Figure 4. Export of goods and services (\% of GDP).

Source: World Bank National Accounts data and $\backslash$ OECD National Accounts data files. 
We see this figure grow gradually, this shows that the demand line is always increasing $(\mathrm{M})$ compared to that of the supply (X). Importation has advantages for the consumer (greater choice of products, better price competition) and a spur of competitiveness for producers.

\section{Perspective on the CAR}

The Central African Republic is a country that had its independence on 13 August 1960 and colonized by the French, the long officially spoken is French and Sango. The Central African Republic is a landlocked country through its geographical position, that is to say without access to the sea. Its population is estimated at 5745135 inhabitants in 2018, for an area of about $623000 \mathrm{~km}^{2}$, with a density of 9.22 inhabitants / $\mathrm{km}^{2}$, a GDP of USD 1.756 billion (2016) is a GDP / habit worth USD 382 USD 2017. It is surrounded by Cameroon to the west, Chad to the north, Sudan and South Sudan in the East, the Democratic Republic of Congo and the Republic of Congo in the South. This country is also a member of the African Union, the Economic and Monetary Community of Central Africa and the Community of Sahelo-Saharan States. The Central African Republic is shared between savanna and equatorial forest (in the South) with a tropical climate. The country also has many natural resources including uranium, gold, diamonds and oil. Some of these resources are exploited in a rudimentary way but many are still not exploitable.

\subsection{The Determinants of Economic Growth in CAR}

These determinants are linked to several factors allowing effective and sustainable economic growth through these sub-elements that we were going to address in a rather broad way. The determinants of economic growth are nothing more than the resources held by a country like CAR, considering these assets as beneficial to sustainable development.

\subsection{The Primary Sector}

The majority of the Central African population lives in rural areas and agriculture is a key sector in the Central African economy occupying $65 \%$ of the active population and contributing on average to more than $60 \%$ to the formation of the gross domestic product (GDP). The main food crops are; Cassava, Mil, Peanut, Sorghum.

1. Livestock accounts for more than $24 \%$ of agricultural GDP. Three farming methods are practiced: pastoral, transhumant and sedentary;

2. Fishing and hunting: fishing, currently unregulated, is practiced on the Oubangui River and the most important of its tributaries, as well as the flood plains of the North-East. No industry represents it and fish farming remains the business of farmers and rural development services. Estimates of annual production are 13,000 tonnes. Hunting brings significant income to the CAR;
3. The forest: is one of the richest in the world in rare species. It covers $5.5 \%$ of the area of CAR, or 34 million hectares, of which 2 million are exploitable. Central African Wood flows mainly to the European and North American markets which, because of the economic crisis, have reduced their demand.

\subsection{The Secondary Sector}

The Central African Republic does not register many processing industries. There are only a few such as drink, candy, cigarette making, sheet metal, etc. All these activities remain in an embryonic state, in 2008, the manufacturing industries recorded an increase of $0.40 \%$. It is a country that has gone through very dark moments of its history by multiple forms of violence (coup d'Etat, rebellion etc.). All this does not prevent it from believing in its development, its GDP growth should accelerate to reach $4.7 \%$ in 2017 , then $5 \%$ in 2018 despite its current situation. To fight against poverty $(76 \%$ according to the World Bank) and to meet vital needs, the Central African State has had funding from IBRD (International Bank for Reconstruction and Development) and IDA (International Development Association). We will therefore present graphically these 2014 financial until 2018 below.

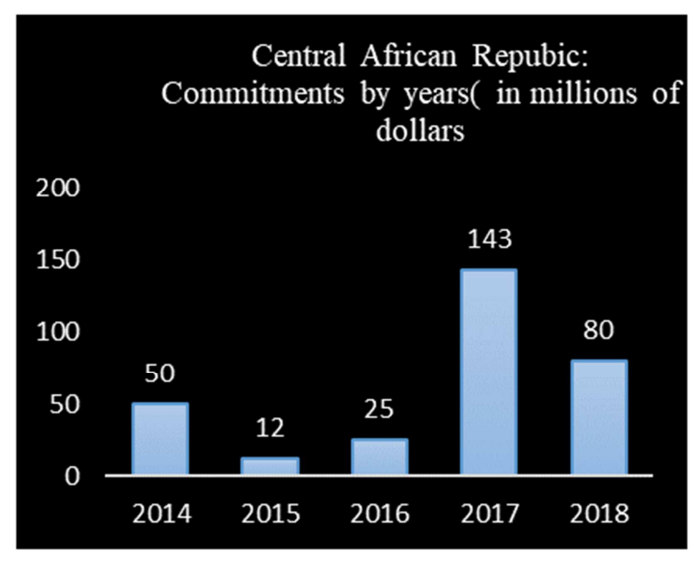

Source: World Bank in Africa

Figure 5. Funding from IBRD and IDA to the Central African Republic.

\subsection{The Tertiary Sector}

The tertiary sector is one of the pillars of a country's development through infrastructure and transport. So the CAR is served by the Equatorial Trans Route to Congo and the road to Douala (Cameroon). Central African information technology and communication infrastructures are inadequate and obsolete Khadoroo, J \& Seetanah, B.2010 [18]. The inadequacy of these services therefore constitute a major blockage to the evolution of a good quality of the internet. Because the internet has become the locomotive of large firms to carry out commercial transactions (E-commerce, $\mathrm{M}$-commerce etc.). We will therefore present the number of Internet users in CAR from 1996 to 2011 below. 


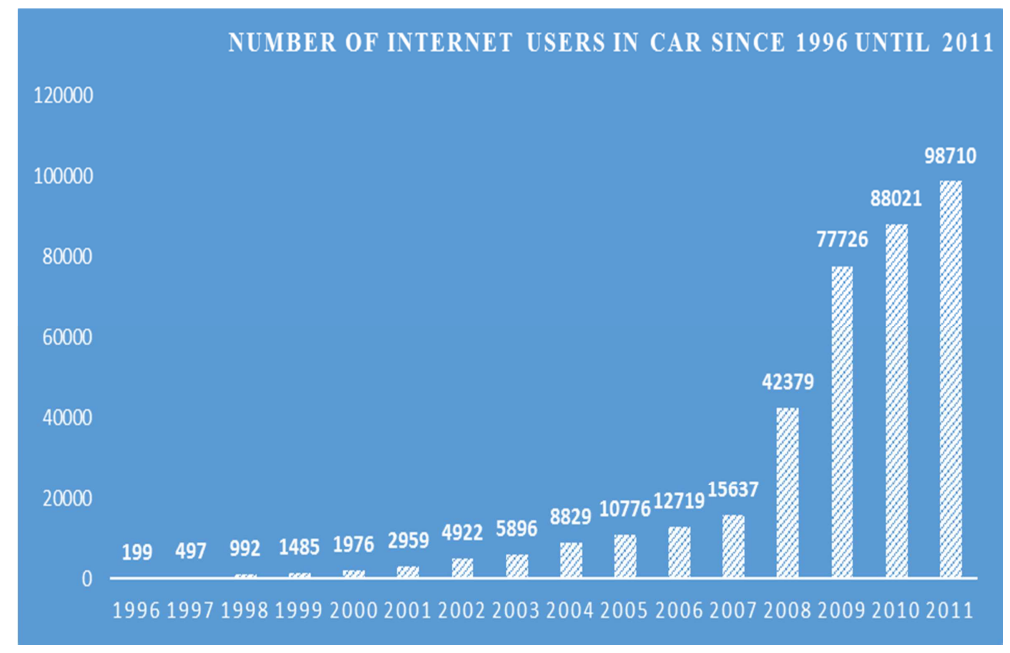

Source: Royce Fund

Figure 6. Evolution of the number of Internet users in CAR.

Looking at the evolution of this graph, it is not comparable to that of Cameroon. Taking the example of 1997 which is estimated at 990 against that of the CAR is estimated at 199 is to say that there is 791 difference of Internet users, just like the year 2011 is to 1001518 vs 98710 . So seen at the geographical position of this country, it depends much more from outside to stock up on its vital needs. This country has signed a lot of cooperation agreements by allowing it to get out of its isolation, the table below will show us the different countries to which this country can export or import manufacturing products as following

Table 1. The main partners of the CAR (Source: Comtrade, latest available data).

\begin{tabular}{llll}
\hline Main Customers (\% of Exports) & $\mathbf{2 0 1 6}$ & Main Suppliers (\% of Imports) \\
\hline France & $48,6 \%$ & France & 2016 \\
Burundi & $14,2 \%$ & Japan & $21,1 \%$ \\
China & $10,2 \%$ & United States & $11,3 \%$ \\
Cameroon & $8,4 \%$ & China & $9,9 \%$ \\
Germany & $3,7 \%$ & Italy & $8,8 \%$ \\
Vietnam & $3,5 \%$ & Cameroon \\
Austria & $2,1 \%$ & Netherlands & $7,1 \%$ \\
Belgium & $2,0 \%$ & India & $4,9 \%$ \\
Iceland & $1,3 \%$ & UK & $4,7 \%$ \\
Chad & $0,9 \%$ & Denmark & $3,6 \%$ \\
\hline
\end{tabular}

Through imports and exports by the Central African Republic can bring more productivity gains which in turn favor the increase of its GDP. But unfortunately, alongside its exports many products are exported in a raw way or these products need to be transformed first to the finished state which is the source of the creation of new jobs alongside small and medium-sized enterprises in order to derive economic growth. The exports of Central African products in their raw state constitute a shortfall on the part of the government, which is why the trade balance is still in deficit. So, we will graphically represent the level of imports and exports of the CAR's manufacturing products below:

Imports from the Central African Republic are growing, the main reason is due to its isolation from the rest of the world, so it depends more on the outside by various product categories.

CAR exports are trending down on the graphic. Economically speaking, the country does not hold manufacturing companies for semi-finished products in the finished state through the determinants of economic growth (tertiary, secondary, etc.) Saget. C. 2000 [19]. Agriculture and livestock account for more than $89 \%$ of GDP, so we will have to put a lot of emphasis on that to fight poverty. Thus, we will graphically represent products exported from the CAR below:

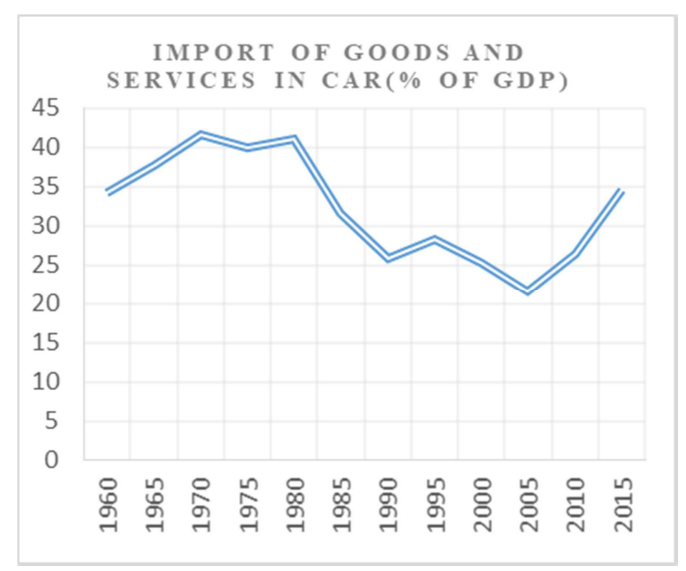

Figure 7. Import of goods and services in CAR (\% of GDP).

Source: World Bank National Accounts and $\backslash$ National Accounts Data Files from the OCDE. 


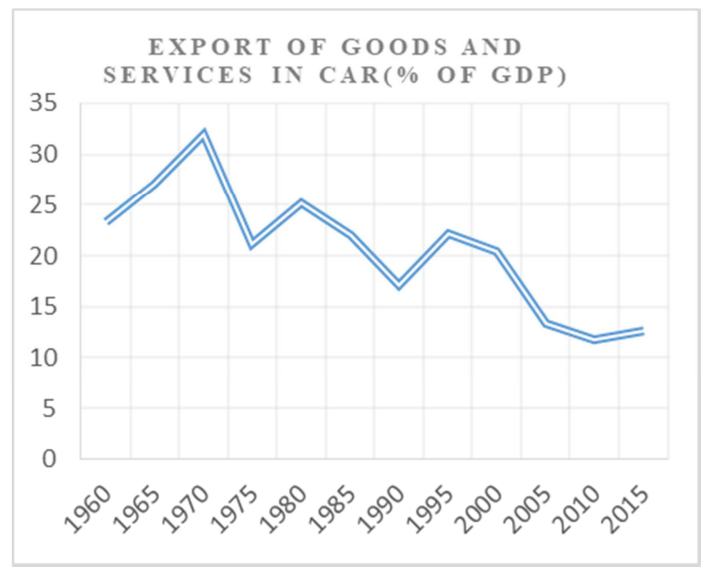

Figure 8. Export of goods and services in CAR (\% of GDP).

Source: World Bank National Accounts and National Accounts Data Files from the OCDE.

CAR exports are seen in the face as a saw tooth, the reason may be due to the different events that CAR is going through. There is also a lack of the major product processing industries that require a lot of investment from the government with equally effective and rigorous follow-up measures. Since the CAR's exports and imports are not proportional, there will inevitably be an imbalance, especially from the products exported. So there is still a trade deficit that is a shortfall on the part of the Central African government. So, we will present graphically below:

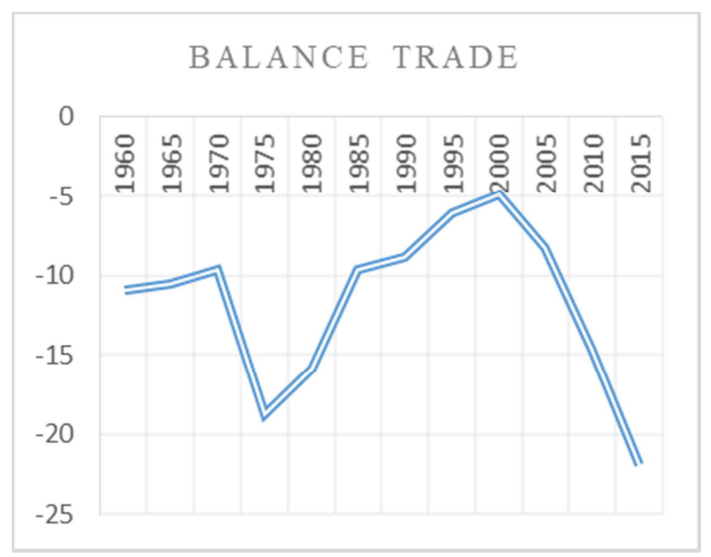

Figure 9. Trade balance.

Source: National Accounts Data from the World Bank and $\backslash$ OECD National Accounts Data Files

Trade deficit deficiencies are disproportionately the products exported against imported products, the case of the CAR. The trade balance of goods and services is the difference between exports of goods and services and imports of goods and services as a percentage of GDP. A positive balance indicates that exports exceed imports by value (trade surplus). On the contrary, a negative balance indicates that imports exceed exports by value (trade deficit). For the whole period 1960-2017, there is an annual average of -10.17 . The change between the first and last year is $77 \%$. The highest value was recorded in 2003 (0.24) and the lowest value was recorded in $2014(-24.53)$. We have results for 58 years. To see a little more clearly, also compare with other countries in the region as the case of Congo, Gabon, Equatorial Guinea, Cameroon.

\section{Summary}

This article focuses on the determinants of economic growth in the Central African Republic while beginning with a keynote introduction through their different definitions. The author of this article was able to make a theoretical literature on the determinants of economic growth as the pivot of a sustainable development of an entire country. From this literature, the author has also been able to highlight the endogenous and exogenous growth theory with divergent points of view in relation to these determinants. The author has not forgotten to highlight the aspect of the empirical literature of the determinants of economic growth while highlighting the salient points that the RCA confronts (primary, secondary, tertiary sector) while also relying on data graphically to see the momentum of each curve

\section{Recommendations}

The purpose of this article is to give a number of strong recommendations at the end of this study, will allow the Central African Republic to take certain aspects seriously leading towards the path of its development. Then the points mentioned above seem to us essential in the macroeconomic activities, are as follows:

1. Transform all our universities (public \& private) to a university of development ie based on the technicality, specificity and associated all our academics in major decisions (economic, political, cultural etc.)

2. Consider the university as the center of knowledge and solutions to any problem that affects the life of the city (knowledge, know-how and know-how to do;)

3. Strengthen the capacity of teachers and professors, that is to say, make them undergo much more at different training workshops (more than $45 \%$ of the GDP must be devoted to the construction of schools and the training of teachers and teachers;

4. Train students in the expectation of the needs presented in the job market, ie by supporting them and orienting them much more towards entrepreneurship after completing their studies (small and medium-sized enterprises);

5. To make the agronomic sector more essential for it to have food self-sufficiency, because the investment of today will make the happiness of tomorrow after

6. Macroeconomic stability allows such a simple experience on East Asian countries, shows sound and prudent macroeconomic management to have a positive effect on growth.

\section{Conclusion}

This article draws its conclusion by strong 
recommendations allowing the Central African Republic to target these points enumerated by the author of this article, to look forward to thereat Jayakumar, A. Kannan, L\&Anbalagan, G. 2014 [20]. The development of an entire country always passes by major theories macroeconomic on a strict application in its generality, proof is that the author has made use of these different theories for the path of a country towards sustainable development. So this article is divided into three major parts that the author could 'first introduce while releasing the keywords of the theme in question. He was also able to identify major macroeconomic theories based on his own arguments submitted to the Central African government. The author also made a retrospective on the history of the CAR in a process of development while bringing a situation closer to that of South Korea. The average income of a South Korea is ten times higher than that of a Central African today, while in 1960 the average income of a Central African was higher than that of a South Korea. So we say, poverty is not inevitable, as long as the macroeconomic rules are respected and the direction of investment in the various activities listed by the author of this article is also respected, the CAR can then move forward.

\section{Acknowledgements}

Doing publication is the best way to be recognized internationally as well with relevant topics like mine, attracting the world of scientists. As a result, writing a publication is a concise but difficult task, so it will take longer to read the documents that relate to the topic to be addressed. To this I would like to thank very much my former colleagues at Chongqing University of Posts and Telecommunications and in particular Mr. ACAPKO-ADDRA Codjo Novignon for giving me more foresight in a publication work. Evidence has shown the course of the various documents to achieve meaningful work. I also want to thank my supervisor $\mathrm{Mr}$. Wu Xiang Feng who gave me the taste of this particular work and the writing of a dissertation in a general way.

\section{References}

[1] Mankiw, G., D, Romer and D. Weil, "A contribution to the Empirics of Economic Growth" Quarterly Journal of Economics, Vol. 107. 407-437, 1992.

[2] Benhabib, J. and A. Rustichinia "Social Conflict, Growth and Income Distribution", Journal of Economic Growth. PP. 125-142, 1996.

[3] Englander and Gurney, Dasgusta, P. and J. Stiglitz, "Learning-by-doing, Market Structure and Structural, Trade Policies" Oxford Economic Papers. Vol 40. PP. 246-268, [1994] [1988].

[4] Coe, Helpman and al. "North-South R and D Spillovers" The Economic Journal, Vol. PP. 134-149, 1997.
[5] Becker, Kevin and al., "Human Capital and Economic Growth", Journal of Political Economy, Vol.90 Part 2. PP. S12-37, Adam Smith [1776] [1990].

[6] Nnadosie E. Osili U. O. 2004, US. Foreign Direct Accumulation" Journal of Economic Growth. PP. 333-350, David Ricardo 1819.

[7] Thomas Malthus, John Stuart Mill 1798, Barro, R. J., "Economic Growth in a cross-section of countries: Quarterly Journal of Economic, Vol 106. PP. 407-443, [1798] [1991].

[8] Harrod-Domar, Robert Solow. "Capital Extension, Rate of Growth and Employment" Econometrica no 14. PP 137-147 1946.

[9] Lucas and Romer, "On the Mechanics of Economic Development". Journal of Monetary Economics, Vol 22. PP. 3-42, 1988.

[10] Grossman, I. H. and M. Kim 1996" Predation and Accumulation" Journal of Economic Growth. PP. 333-350, Feenestra 1990.

[11] Römer, Mankiw, G, Barro, R J. "Human Capital and Growth" American Economic Review, Vol 91. PP 12-17 2001.

[12] Römer, Levine, Renelt and al. "A Sentivity Analysis and Cross-country Growth from Regression" American Economic Review, Vol 82, PP. 942-963 [1986] [1992].

[13] Ballassa, B. "Export and Economic Growth: Further Evidence", Journal of Développement Economics, vol. 5(2), pp.181-189. [1978]

[14] Bassani and Scarpetta, Lucas and Romer, "On the Mechanics of Economic Development". Journal of Monetary Economics, Vol 22. PP. 3-42 [2001] [1988].

[15] Arellano. M. and S. Bond. "Some test of specification for panel Data: Monte Carlo Evidence and an application to employment equations: The review of economic studies: P. 277-297, 1991

[16] Tornell, A. and A. Velasco, "The tragedy of Commons and Economic Growth: Why does Capital flow from rich to poor countries" Journal of Political Economy. PP.

[17] Alesina, A. D. Rodrik, "Distributive Politics and Economics Growth", Quarterly Journal of Economics, Vol.109, Issue 2, PP. 465-490, 1994.

[18] Khadoroo, J \& Seetanah, B. Transport, Infrastructure and FDI: Lessons from sab-saharan African Economies. Journal of International Development. PP. 103-123, 2010.

[19] Saget. C. Can GDP Growth in transition countries explain the level of employment. (Theory vesus the quality of Data) Review of Labor economics and Industrial relations: P. 623-643, 2000.

[20] Jayakumar, A. Kannan, L \& Anbalagan, G. 2014, Impact of Foreign Direct Investment (FDI), Import \& Export. International Review of Research in Emerging Markets and the Global Economic. PP. 51-58. 